\title{
Megathrust Earthquake Potential of the Manila Subduction Systems Revealed by the Radial Component of Seismic Moment Tensors Mrr
}

\author{
Jing-Yi Lin ${ }^{1,2, *}$, Wen-Nan $\mathrm{Wu}^{3}$, and Chung-Liang $\mathrm{Lo}^{1}$ \\ ${ }^{1}$ Department of Earth Sciences and Institute of Geophysics, National Central University, Taoyuan City, Taiwan, R.O.C. \\ ${ }^{2}$ Center for Environmental Studies, National Central University, Taoyuan City, Taiwan, R.O.C. \\ ${ }^{3}$ Institute of Earth Sciences, Academia Sinica, Taipei, Taiwan, R.O.C.
}

Received 1 September 2012, revised 26 April 2013, accepted 29 April 2013

\begin{abstract}
We undertook an investigation of the seismic behavior of large earthquake and estimated the crustal deformation state in the northern Philippine area in terms of the radial component of seismic moment tensors (Mrr) distribution. Based upon these two analyses, the seismic potential of the Manila Trench has been assessed. Regarding the seismic characteristics of large earthquakes, results show that both the overriding and the subducting plates are under compressive stress before the main large events but are characterized by an extensional regime after mainshocks. In the northern Manila Trench area, the broad zone of extensional seismic activity along the trench and its neighboring areas shows a stress environment distinct from that of the interseismic environment of large earthquakes, suggesting that the plates are in a relaxed state instead of accumulating tectonic stress. Thus, the coupling between the two plates could be weak. Along the central Manila Trench, even though only few extensional earthquakes occurred near the trench, numerous negative Mrr events in the overriding plate indicate that the crust is affected by a dilatational regime and also suggests a relatively low coupling environment. In the southern Manila Trench, with the exception of a few extensional events that occurred locally in the Central Valley Basin, most earthquakes show compressive mechanisms. We suggest that a relatively high plate coupling exists along this portion of the trench and results in stress accumulation not only along the plate interface but also in its vicinity, within the subducting and overriding plates.
\end{abstract}

Key words: Manila Trench, Seismic potential, Seismogenic zone, Seismic moment tensor

Citation: Lin, J. Y., W. N. Wu, and C. L. Lo, 2015: Megathrust earthquake potential of the Manila subduction systems revealed by the radial component of seismic moment tensors Mrr. Terr. Atmos. Ocean. Sci., 26, 619-630, doi: 10.3319/TAO.2013.04.29.01(TC)

\section{INTRODUCTION}

Since the 2004 great Sumatra-Andaman earthquake, the tsunami generation potential along subduction systems all over the world has been studied, and several high-risk areas have been noted (Gusiakov 2005; Kirby et al. 2006; Cummins 2007; Liu et al. 2007). Among them, the Manila Trench, where the Eurasian plate is actively subducting eastward underneath the Luzon volcanic arc adjacent to the Philippine Sea plate, was identified as a high-potential earthquake zone (Kirby et al. 2006; Liu et al. 2007). Previous studies show that no earthquake larger than $\mathrm{Mw}=7.6$ has been recorded in the past 100 years in the Manila Trench region; however, the strain has been accumulating over a period of 440 years, and a giant earthquake of moment magnitude $(\mathrm{Mw}) \sim 9$ could

\footnotetext{
* Corresponding author

E-mail:jylin.gep@gmail.com
}

be expected (Wu and Huang 2009). Based on this assumption, several simulations of tsunami generation have been conducted to establish a tsunami early warning system (Dao et al. 2009; Liu et al. 2009; Megawati et al. 2009; Wu and Huang 2009). To prevent such a disaster, it is reasonable to conduct tsunami simulations based upon a worst-case scenario, the occurrence of an $\mathrm{Mw} \sim 9$ earthquake. However, detailed seismic potential studies along the Manila Trench area are still needed to improve the bases for tsunami forecasts.

Many studies have tried to identify a universal law for the seismogenic behavior of great earthquakes, such as the change in background seismic activity and focal mechanism pattern (Christensen and Ruff 1988), the presence of seismic gaps (Ruff and Kanamori 1980; Peterson and Seno 1984; Pacheco et al. 1993) and the distribution of repeating earthquakes (Uchida and Matsuzawa 2011). Certain statistical 
behaviors that are related to the process of stress accumulation in the Earth's crust and that manifest before great earthquakes have been reported (Kanamori 1981; Mogi 1984; Scholz 1988; Wyss and Habermann 1988; Keilis-Borok and Kossobokov 1990; Turcotte 1991; Lomnitz 1994; Telesca et al. 2003; Ramírez-Rojas et al. 2004). All of the studies suggested that the occurrences of large subduction zone earthquakes do seem to follow some systematic patterns. Since 2004, there have been three mega quakes with Mw greater than or equal to 8.8 in Sumatra, Japan, and Chile. The unprecedented seismological datasets recorded by global seismic networks before and after these great earthquakes could certainly provide more information for further analyses of the generation of large earthquakes.

In our study, we examined the radial component of seismic moment tensors (Mrr) tensors of earthquakes to understand the crustal deformation regime around the study area. Simultaneously, we identified the seismogenic behavior of the recent great earthquakes by discussing the variations in the pre- and post-seismic patterns. We then compared the stress state of the Manila subduction system and the seismogenic characteristics determined from the recent large earthquakes with the goal of estimating the seismic potential for the Manila Trench area.

\section{GEOLOGICAL SETTING}

The Manila Trench subduction zone is an active convergent plate margin between the South China Sea and the northern Philippines (Ludwig et al. 1967; Hayes and Lewis 1984) with a convergence rate of $80-100 \mathrm{~mm} \mathrm{yr}^{-1}$ (Seno et al. 1993; Yu et al. 1999; Sella et al. 2002). The convergence rate decreases gradually southward along the Manila Trench which is most likely due to the Palawan-Mindoro collision at the southern termination of the Manila Trench (Galgana et al. 2007). Trending northerly, the trench is associated with a volcanic arc (East Luzon Ridge in Fig. 1), an east-dipping Wadati-Benioff zone beneath Luzon and a well-developed forearc basin system (Lewis and Hayes 1989). The Luzon Trough forearc basins lie landward of the Manila Trench and contain up to $4.5 \mathrm{~km}$ of sediments (North and West Luzon Trough in Fig. 1) (Hayes and Lewis 1984). Multichannel seismic reflection profiles reveal that trench strata folding and thrust faulting occur at the base of the trench slope (Ludwig 1970). Faulting and uplift occur within a narrow zone of the forearc (e.g., Vigan High), where seamounts associated with the relict spreading center of the South China Sea basin have presumably been subducted. The oblique convergence between the Philippine Sea Plate and the Sunda Block/Eurasian Plate has decomposed into a trench-parallel component of 20 - $25 \mathrm{~mm} \mathrm{yr}^{-1}$ on the Philippine Fault system (Barrier et al. 1991) and a trench-perpendicular component of $40-90 \mathrm{~mm} \mathrm{yr}^{-1}$ on the Philippine and Manila Trench (Fig. 1) (Galgana et al. 2007). Convergence also exists to the east of Luzon along the East Luzon Trough as evidenced by the presence of deep bathymetry, well-defined negative gravity anomalies, and high seismicity (Bautista et al. 2001).

Relatively light to moderate shallow seismicity characterizes the Manila Trench area. In its overriding plate and the outer rise area, a zone of dense to moderate clustering of shallow epicenters is seen starting from approximately $15^{\circ} \mathrm{N}$ to approximately $22^{\circ} \mathrm{N}$ (Bautista et al. 2001). In the southern

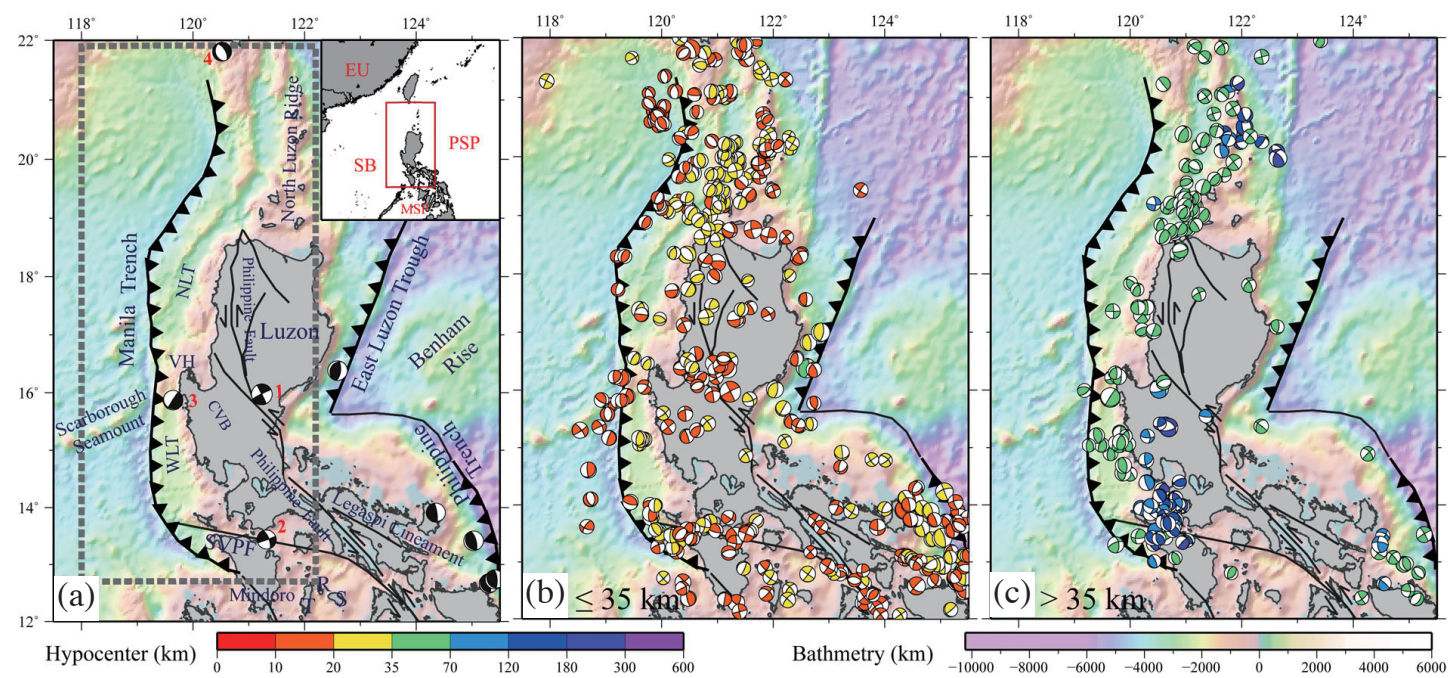

Fig. 1. (a) Tectonic framework in the Manila subduction zone. The study area is shown by the red rectangle in the inset figure. Black focal mechanisms show earthquakes of magnitudes greater than 7 in the Global CMT catalog for the period from January 1976 to November 2011. Black lines show the main tectonic structures. EU: Eurasia Plate; PSP: Philippine Sea Plate; MSP: Molucca Sea Plate; SB: Sunda Block; NLT: North Luzon Trough; VH: Vigan High; WLT: West Luzon Trough; CVB: Central Valley Basin; SVPF: Sibuyan Verde Passage Fault. (b) and (c) show the earthquakes at depths shallower and deeper than $35 \mathrm{~km}$, respectively. The color of focal mechanisms indicates depth. The tectonic structures are adapted from Yang et al. (1996). 
end of the Manila Trench, the trench morphology bends sharply, and high-density intermediate-depth seismicity exists; this seismicity could be associated with the deformation of the subducted Eurasian plate beneath the trench (Lin and Lo 2013). Much of the activity in the northern Luzon block is localized along the Philippine Fault and its splays.

The stress regime of the northern Manila Trench area (to the north of $18^{\circ} \mathrm{N}$ ) has been investigated (Kao et al. 2000; $\mathrm{Wu}$ et al. 2010). Based on the characteristics of earthquake distribution and source parameters, the region between about 21.5 and $23^{\circ} \mathrm{N}$ corresponds to a transition from the typical subduction process along the Manila Trench to the active collision in Taiwan (e.g., Kao et al. 2000; Tang and Chemenda 2000; Wu et al. 2010). To the south of this transition zone, the Manila Trench-Luzon Arc system shows typical subduction features in both bathymetry and earthquake source parameters. The tectonic stress near the trench axis is dominated by a complex extension regime, which is often interpreted as the consequence of plate bending in a $\sigma_{3}$ direction perpendicular to the strike of the trench axis. The seismogenic portion of the plate interface is characterized by a group of events showing low-angle thrust faulting mechanisms and a dipping Wadati-Benioff Zone. At depths between 100 and $150 \mathrm{~km}$, the state of strain within the slab is downdip extension and then changes to a downdip compression at greater depth (Kao et al. 2000). Meanwhile, the shallow part of the forearc area is characterized by strike-slip mechanisms with an E-W or NW-SE $\sigma_{3}$ direction (Wu et al. 2010).

\section{CRUSTAL DEFORMATION REVEALED BY MRR}

Detailed geological structure investigations and GPS observations provide information on the present-day crustal deformation and are often used to resolve tectonic problems. However, in marine areas, geological field observations are difficult, and the geodetic network coverage is limited. Under these constraints, a seismic data analysis could be a better approach to deduce the current stress regime in marine areas. When an earthquake occurs, the seismic moment tensor is a complete description of the earthquake size and source geometry. Its six components, Mrr, Mtt, Mpp, Mrt, Mrp, and Mtp, where $r$ is up, $t$ is south, and $p$ is east, mainly describe the displacement field from a seismic source caused by force couples acting on particular planes. In our study, we exploited only the sign of one component, the radial component of the centroid moment tensor solution (Mrr). Positive and negative Mrr values represent the upward and downward slips during an earthquake that contribute to crustal thickening and thinning effects, respectively. Therefore, the stress state (compressive and tensional) of a seismic active area can be derived based on the Mrr. Several previous studies have shown that the presence of the compressive stress state is generally considered as undertaking a strong coupling mechanism and extensional stress as weak coupling (Astiz et al. 1988; Lay et al. 1989; Taylor et al. 1996). In this case, the link between the Mrr value and the coupling status of a subduction zone can be established. The main reasons for using the Mrr in our study are as follows: (1) Complex tectonic environments generally illustrated by focal mechanisms with various fault orientations can be simplified only by compressive and extensional mechanisms. This procedure can help us to more easily determine the main stress regime without confusion with other fault configurations. (2) Strike-slip events often contain some compressive or extensional component that is generally minor and difficult to observe when inspecting its focal mechanisms. The Mrr analysis allows us to extract the stress contribution of a strike-slip event in the vertical component. (3) Unlike other marine geophysical, geological, and geodetic data, the global seismic data can be accessed without too much difficulty.

Based on available geophysical and geochemical data, the crustal thickness of the Luzon Island has been estimated to range from approximately $20-35 \mathrm{~km}$ (Dimalanta et al. 2002; Dimalanta and Yumul 2004, 2006; Yumul et al. 2008). Because the earthquake generation mechanisms in the crust and mantle could be different, we took $35 \mathrm{~km}$ as the depth boundary and separated our dataset into crustal and mantle portions in the following analyses to clarify our discussion. The Mrr used here was retrieved from the global centroid moment tensor (GCMT) catalog (http://www.globalcmt. org/CMTsearch.html) from 1 January 1976 to 30 November 2011 (Dziewonski et al. 1981; Ekström et al. 2012) (Fig. 1). Although some hypocentral mislocations are expected, previous experience (Kao and Chen 1991; Kao et al. 1998) indicates that the uncertainties are tolerable in depicting the overall geometry of the subducted slab as well as the general seismic patterns due to the excellent azimuthal global network coverage for earthquakes occurring in the western $\mathrm{Pa}$ cific region. However, to ensure that the earthquake classification and our result will not be changed by the lateral depth variation of the forearc Moho and the hypocenter location uncertainty, we will perform our calculation by using different boundary depths for determining the crustal and mantle portions. The results of using 25 and $30 \mathrm{~km}$ boundary depths will be presented in section 5 , and we will demonstrate that no significant differences result from using 20,30 , and $35 \mathrm{~km}$ as boundary depths.

Figure 2 shows the distribution of the Mrr solutions, which are presented to show a temporal variation. The predominance of a positive Mrr is mainly the result of thrusting events from the entire depth range and shows an ongoing subduction process along the Manila Trench system. However, many negative Mrr values are also observed. Among them, the events at depths greater than $120 \mathrm{~km}$ primarily result from the slab down-dip extension, as shown by the focal mechanism distribution (Fig. 1c). Otherwise, the events with hypocenters shallower than $35 \mathrm{~km}$ (red bars in Fig. 2), obtained from both 
extensional and strike-slip type earthquakes, seem to have more complex origins. It is worth noting that all $\mathrm{Mw}>7$ earthquakes in our study area have negative Mrr values (numbered stars in Figs. 1a and 2), which suggest a significant influence of crustal thinning effects in the area.

To examine the cumulated Mrr spatial distribution along the Manila subduction system, we divided the study area into 0.2-degree by 0.2-degree grids. The Mrr from all earthquakes in a grid were summed. The cumulative Mrr distribution for earthquakes shallower than $35 \mathrm{~km}$ shows that the crust is actively thinning along the northern portion of the Manila Trench and along the strike-slip Philippine Fault system and its branches (negative Mrr, presented by black dots in Fig. 3a). Meanwhile, most Mrr obtained from the earthquakes deeper than $35 \mathrm{~km}$ are dominated by positive values except for the East Luzon Ridge area, northern offshore Luzon. The Mrr distribution shows that the crustal portion of our study area is primarily controlled by a tectonic thinning effect (extension). However, a compressive regime seems to be dominant for the deeper part. From the Mrr dis- tribution in the crustal part (shallower than $35 \mathrm{~km}$ ), we also observed some variation along the trench. Extensive negative Mrr appeared along the trench and in the outer-rise areas of the northernmost Manila Trench. However, this negative Mrr pattern seems to move landward from the trench to the Philippine Fault area south of approximately $18^{\circ} \mathrm{N}$.

Therefore, based on the spatial Mrr distribution, we suggest that the crustal portion (shallower than $35 \mathrm{~km}$ ) of both the subducting and overriding plates is affected by dilatational motion, especially along the northern Manila Trench area and the Philippine Fault system. Beneath the crust, the present tectonic activities seem to be mainly controlled by the subduction process, which is represented by a positive Mrr.

\section{SEISMOGENIC BEHAVIOR FOR LARGE EARTHQUAKES}

Even though global observations at the subduction zones reveal a large range in seismogenic behavior due to variations in age and the convergence rate of the subducting

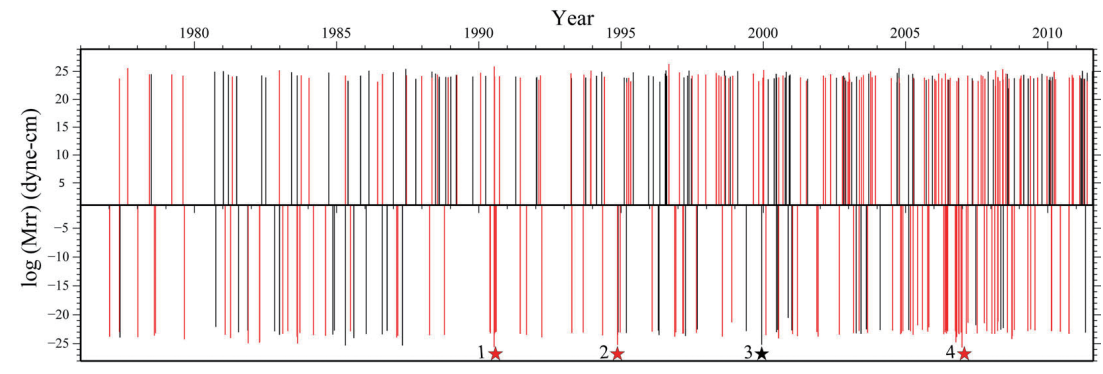

Fig. 2. The radial component of seismic moment tensors (Mrr) for the earthquakes located in the gray dotted area in Fig. 1a. The red and black bars show the Mrr from the earthquakes shallower than $35 \mathrm{~km}$ and deeper than $35 \mathrm{~km}$, respectively. Numbered stars show the Mw $>7$ earthquakes located in the dotted area in Fig. 1a.

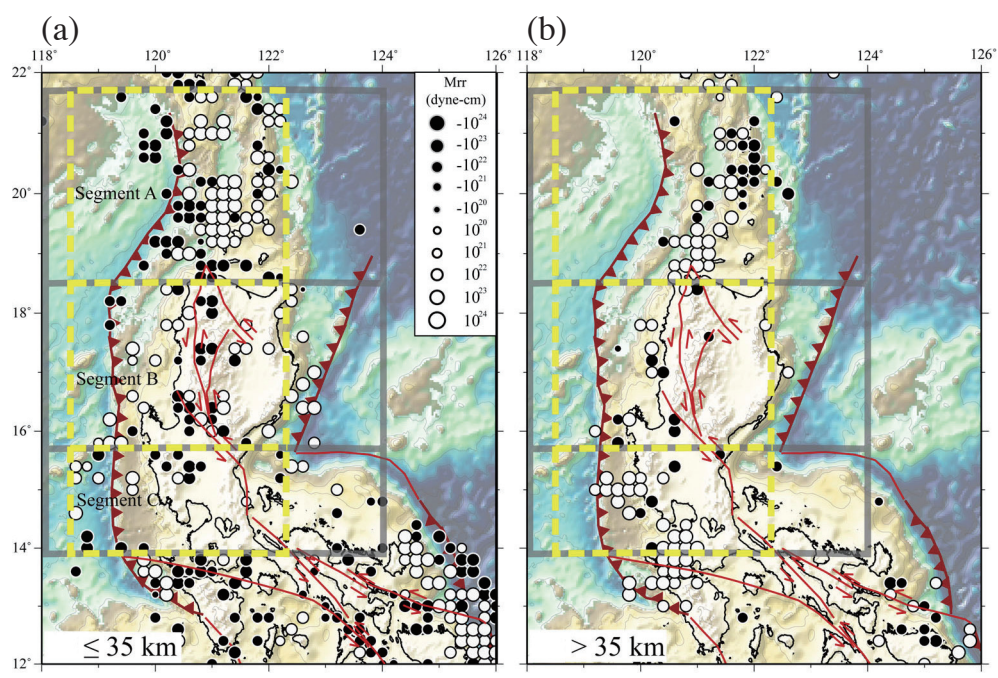

Fig. 3. Distribution of the cumulated Mrr in the Manila Trench region calculated from the earthquakes from 1976 - 2011 in the Global CMT catalog. Earthquakes for the depth ranges of (a) 0 - $35 \mathrm{~km}$ and (b) larger than $35 \mathrm{~km}$ are shown. Compressive tectonic regions usually have positive Mrr (white dots), while extensional regions have negative Mrr (black dots). The dot sizes show the Mrr magnitudes. 
plate (Kanamori 1986), the occurrences of large subductionzone earthquakes do seem to follow some systematic patterns with respect to their segmentation (Thatcher 1990) and the timing of major earthquakes (Sieh et al.2008). Here, we determine the seismic characteristics of megathrust earthquakes by analyzing the variations of the pre- and postseismic patterns of three recent great earthquakes: the 2011 Tohoku (Mw 9.0), 2010 Chile (Mw 8.8), and 2004 SumatraAndaman (Mw 9.2) great earthquakes.

The 2011 Tohoku earthquake ( $\mathrm{Mw}=9.0$ ) occurred near the northeast coast of Honshu, Japan on 11 March 2011. The hypocenter was located by the USGS at $38.322^{\circ} \mathrm{N}$, $142.369^{\circ} \mathrm{E}$ at a depth of $32 \mathrm{~km}$ (black beach ball in Fig. 4b). Before the mainshock, numerous thrusting events occurred along the plate interface and in the forearc area from the trench to the Japanese coast (Fig. 4a). Additionally, several thrusting events occurred in the outer rise area in the oceanic plate (about $37.5-39^{\circ} \mathrm{N}$ ) which showed a dominant compressive stress environment (Fig. 4a). After the mainshock, many extensional events occurred not only in the forearc but also in the outer rise area along the 2011 Tohoku earthquake rupture zone (Fig. 4b). The former shows various fault orientations; however, the latter shows a consistent fault orientation with a fault strike sub-parallel to the trench. No matter the direction of the strike, the occurrences of extensional earthquakes after the mainshocks suggest that most of the stress accumulated during the interseismic period was released both in the subducting and overriding plates. Thus, the compressive stress regime was transferred to extensional after the mainshock.

Located off the coast of the Biobio Region of Chile, the 2010 Chile earthquake $(\mathrm{Mw}=8.8$ ) occurred on 27 February
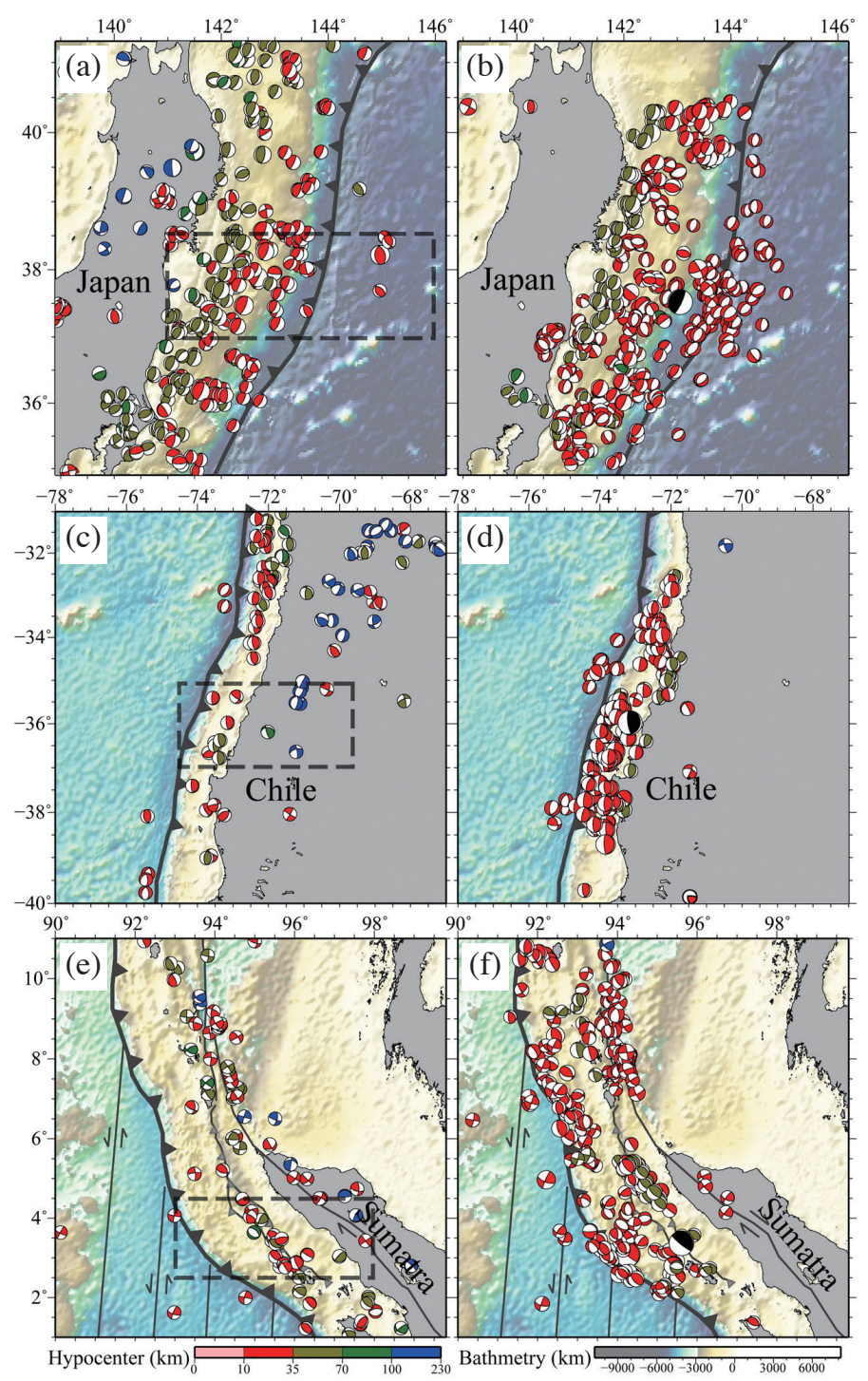

Fig. 4. Pre- and post-seismic focal mechanism distributions of the three recent great earthquakes: (a) (b) the 2011 Tohoku (Mw 9.0 ); (c) (d) 2010 Chile (Mw 8.8); (e) (f) 2004 Sumatra-Andaman (Mw 9.2) earthquakes. (a), (c), and (e) show the pre-seismic focal mechanisms, and (b), (d), and (f) show the post-seismic events. The depth of earthquakes is indicated by the color of the focal mechanisms. 
2010. The hypocenter was located at $35.909^{\circ} \mathrm{S}, 72.733^{\circ} \mathrm{W}$, at a depth of $35 \mathrm{~km}$ (black beach ball in Fig. 4d). Low preseismic activity was observed for the 2010 Chile earthquake where only a few thrusting earthquakes occurred in the forearc area. Some extensional events were also observed pre-seismically in the oceanic plate north and south of the 2010 main rupture zone. Former studies suggested that these pre-seismic extensional events could be linked to the stress release effect of the previous large earthquakes located to the north and south of the 2010 rupture area; these earthquakes include the $1960 \mathrm{Mw} 9.5$ earthquake in the south and the $1985 \mathrm{Mw} 7.8$ earthquake in the north (Delouis et al. 2010; Lay et al. 2010). After the mainshock, many thrusttype events occurred along the main rupture zone accompanied by several extensional earthquakes in the outer-rise area. Similar to the 2011 Tohoku earthquake, the extensional post-seismic events with fault strike sub-parallel to the trench could suggest the release of stress not only along the plate interface but also in the overriding plate after the mainshock.

The great 2004 Sumatra earthquake $(\mathrm{Mw}=9.3)$ (Stein and Okal 2005; Tsai et al. 2005) on 26 December 2004 off the west coast of northern Sumatra was located at $3.316^{\circ} \mathrm{N}$, $95.854^{\circ} \mathrm{E}$ at a depth of $28.4 \mathrm{~km}$ (black beach ball in Fig. $4 \mathrm{f}$ ). Except for some thrust-type earthquakes located in the forearc area, most earthquakes that occurred before the Sumatra mainshock were characterized by strike-slip mechanisms and were located along the oceanic fracture zone, in the undergoing plate, or along the Sumatra fault. The 2004 Sumatra earthquake aftershocks contained not only numerous compressive events located along the trench and beneath the forearc area but also many strike-slip events in the oceanic subducting plate and inland Sumatra. Unlike the postseismic activity observed for both the Tohoku and the Chile earthquakes, no obvious normal events were found in the outer-rise Sumatra area after the mainshock. Meanwhile, by analyzing the Mrr values of the strike-slip events (Fig. 5), we find that the pre-seismic and post-seismic events are dominated by positive and negative Mrr, respectively. Therefore, we suggest that the stress states of the outer-rise area and the overriding plate change from compression to extension after the 2004 Sumatra mainshock, which is consistent with the observations obtained from the 2011 Tohoku and 2010 Chile earthquakes.

To summarize, we find that before large earthquakes, both subducting and overriding plates are under compressive stress caused by the stress accumulation during the interseismic period. After the mainshock, the release of tectonic stress creates an extensional environment and promotes the occurrence of normal faulting earthquakes. Christensen and Ruff (1988) proposed that an increased number of outer rise thrust events indicates an interplate thrust close to the rupture limit, whereas normal faulting events are expected to follow great interplate earthquakes, which supports our result.

\section{DISCUSSION}

Based on previous analyses, we compared the stress state deduced from the Mrr values to the seismic characteristics obtained from the great earthquakes to evaluate the seismic potential of the study area. Generally, the segmentation of a major subduction system usually controls earthquake magnitude and location. Thus, to better analyze the seismic potential of different segments along the Manila Trench, we divided the subduction system into three segments based on the distribution pattern of the focal mechanisms and $\mathrm{Mrr}$ (Figs. 1 and 3). (a)

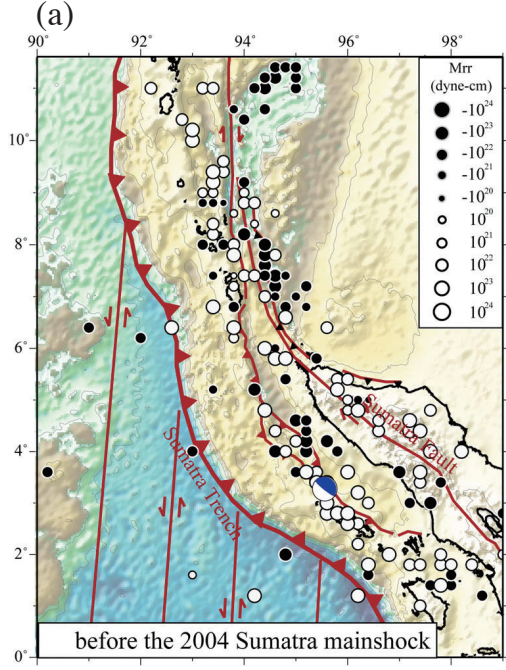

(b)

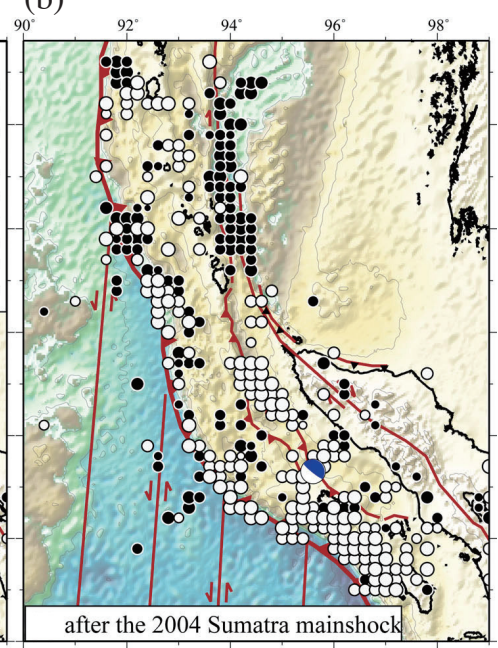

Fig. 5. Distribution of the accumulated Mrr for the Sumatra-Andaman Trench area. (a) Before the 2004 mainshock; (b) after the mainshock. The study area is divided into 0.2-degree by 0.2-degree grids. The Mrr from all earthquakes in a grid were summed. 


\subsection{Cross Sections of Mrr Distribution and Stress State}

The northernmost segment (Segment A) includes the northern part of the Manila Trench, the North Luzon Trough and the North Luzon Ridge (gray rectangle in Fig. 3). Numerous normal faulting events and extensive negative $\mathrm{Mrr}$ distributions reveal an extensional environment along the trench and in its outer rise area (Fig. 6a). This stress regime can also be confirmed by the presence of many high-angle normal fault sequences identified in the northern Manila Trench (Ku and Hsu 2009). Furthermore, the North Luzon Ridge area, where the strike-slip events pre-dominate, is also characterized by negative Mrr values showing that extensional forces also affect the overriding plate. In contrast to the areas mentioned previously, the North Luzon Trough has positive Mrr that could be associated with interplate seismic activity (Fig. 6a). As indicated by the negative Mrr, the current seismic activity of Segment A is different from the pre-seismic patterns of the great earthquakes.

The second segment (Segment B) contains the middle part of the Manila Trench; the Vigan High, where the Scarborough Seamount enters into the forearc, and the Philippine Fault (gray rectangle in Fig. 3). Unlike Segment A, this segment has many fewer normal faulting earthquakes along the trench and outer-rise area. Even so, many nega- tive Mrr are observed along the Philippine Fault (Fig. 3) inland in the Philippines suggesting that the overriding plate is affected predominantly by an extensional stress instead of compressional stress (Fig. 6b). Otherwise, the concentration of positive Mrr in the western and eastern parts of the profile should be linked to the subduction activity along the Manila Trench and East Luzon Trough, respectively (Fig. 6b).

The third segment (Segment C) contains the southern part of the Manila Trench and the West Luzon Trough (gray rectangle in Fig. 3). Except for the local extensional structure located in the Central Valley Basin area, mostly positive Mrr was observed. This dominant positive Mrr distribution implies that the area is affected by a compressive regime probably resulting from the tectonic stress accumulation. In addition, the number of earthquakes in this segment was reduced suddenly which may be associated with the seismic quiescence before large earthquakes that has been reported in seismogenic zones worldwide. Thus, a much larger seismic potential in this segment relative to the two northern segments is proposed.

\subsection{Temporal Variation of the Cumulative Mrr}

More quantitatively, in Fig. 7, we compare the temporal variation of the cumulated Mrr for the three segments along
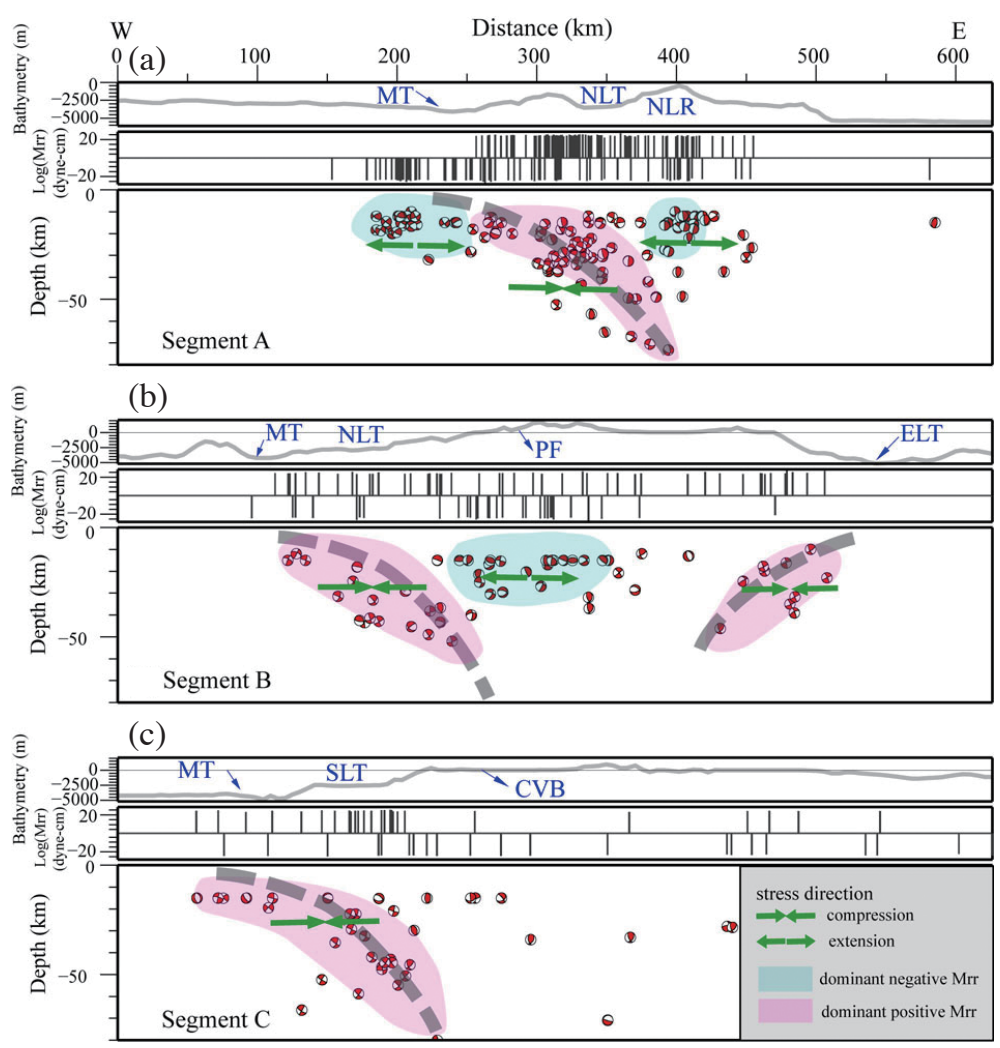

Fig. 6. Cross sections of Segments A, B, and C are shown by yellow dashed rectangles in Fig. 3. Earthquakes were projected along the EW direction. Bathymetry and Mrr are plotted above the three profiles. MT: Manila Trench; NLR: North Luzon Ridge; PF: Philippine Fault; CVB: Central Valley Basin. NLT, ELT, and WLT denote the North, East and West Luzon Trough, respectively. 

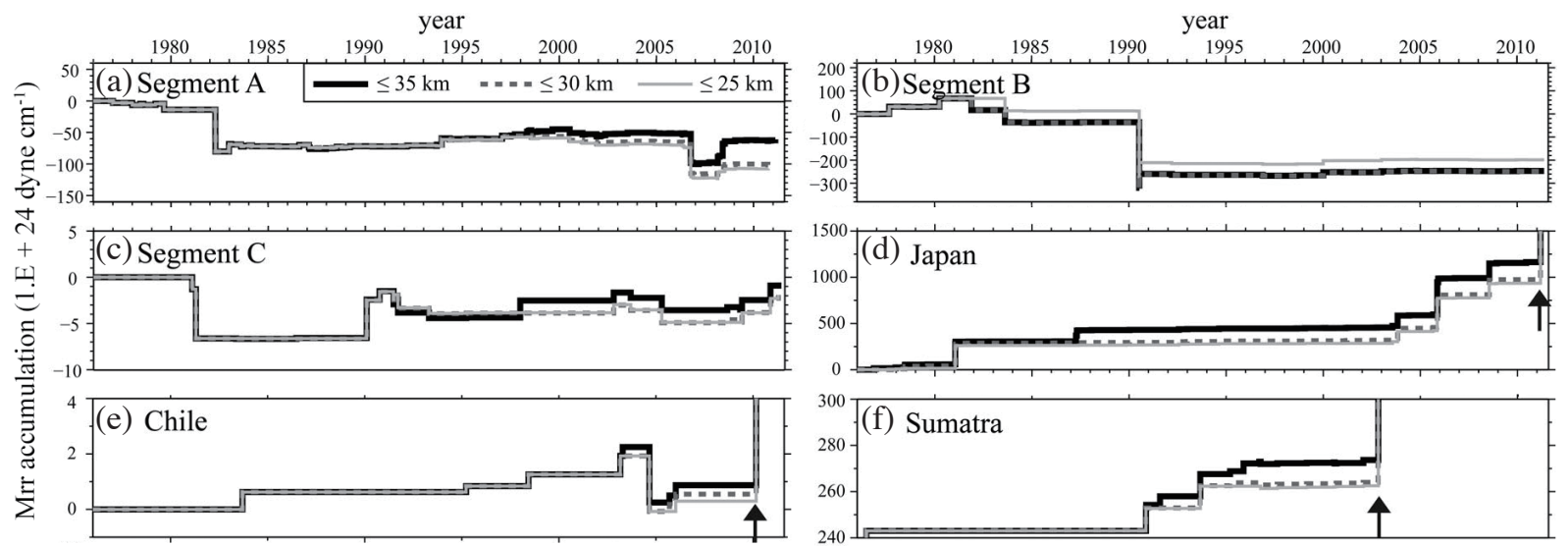

Fig. 7. Temporal variation of cumulated Mrr for the three segments along the Manila Trench in Fig. 3 as well as the three dashed rectangle areas in the vicinity of the Chilean, Japanese, and Sumatran mainshock areas located in Fig. 4. Light gray, gray dashed and black lines show the cumulated Mrr determined using different depth boundaries of 25, 30, and $35 \mathrm{~km}$, respectively.

the Manila Trench (yellow dashed rectangles in Fig. 3) as well as the three gray dashed rectangle areas in the vicinity of the Chilean, Japanese, and Sumatran mainshocks located in Fig. 4. Except for Segments A and B, the surface areas of all other segments are similar, covering approximately 5 degrees of longitude and 2 degrees of latitude, and the surface area of Segments A and B are approximately 1.5 and 2 times greater than the others, respectively. The cumulated Mrr value was set to 0 at the beginning of the earthquake cata$\log$. Firstly, to know the influence of the different boundary depths of the crustal and mantle portions in our calculations, the cumulated Mrr determined from different boundaries of 25,30 , and $35 \mathrm{~km}$ are plotted by the light gray, gray dashed and black lines, respectively (Fig. 7). The result shows that similar patterns are obtained and that using the depth boundary serves only to simplify our discussion and could not affect our result (Fig. 7).

Based on the cumulated Mrr distribution for the three great earthquake areas mentioned in section 4, the 2011 Tohoku (Mw 9.0), 2010 Chile (Mw 8.8), and 2004 SumatraAndaman (Mw 9.2) earthquakes, we find that the cumulated Mrr increases rapidly with time along the Japan and Sumatra subduction zones (Figs. 7d and e). Within the Japanese area, the Mrr increase is contributed uniquely to thrust-type events which generally have positive Mrr values larger than $10^{25} \mathrm{dyne}^{-1}$. One of the largest increases, approximately $3.49 \times 10^{26}$ dyne $\mathrm{cm}^{-1}$, was contributed to an outer-rise thrust-type event of magnitude 7.0 occurring in 2005, suggesting that the outer-area is a strong compressive environment (Fig. 7d). Along the Sumatra area, the Mrr increases are caused not only by the thrust-type events along the plate interface but also by the strike-slip events located along the Sumatra Fault behind the trench in the overriding plate (Fig. 5). Regardless of the case, a dominating compressive stress regime along the high seismogenic potential area could be indicated by the quick increase of Mrr. Surpris- ingly, the cumulated Mrr in the Chilean area had a very low value until the 2010 Chile earthquake (Fig. 7f). Probably due to the scarcity of earthquakes, the accumulated Mrr value varies insignificantly compared to the other two subduction areas. The maximal variation before the 2010 Chile earthquake is approximately $2 \times 10^{24}$ dyne $\mathrm{cm}^{-1}$, only approximately $1.75 \%$ of the largest variation that occurred along the Japan Trench. We suggested that the shortage of the energy release could result from the seismic quiescence induced by the full locked effect along the Chile Trench (Moreno et al. 2010).

Along the Manila Trench (Figs. 7a - c), the cumulated Mrr distribution for the two northern segments (Segments $\mathrm{A}$ and $\mathrm{B}$ ) shows a decreasing trend as a function of time. The lowest value can reach approximately $-1.25 \times 10^{26}$ and $-3.20 \times 10^{26}$ dyne $\mathrm{cm}^{-1}$ for Segments A and B, respectively (Figs. 7a and b). The largest decrease, approximately $-2.83 \times 10^{26}$ dyne $\mathrm{cm}^{-1}$, appeared in Segment B (Fig. 7b) and is induced by a strike-slip type earthquake, the 1990 Mw 7.7 Luzon earthquake that occurred along the Philippine Fault zone in the overriding plate. During this period, even though numerous thrust-type events occurred, their Mrr values were too small to change the pattern from negative to positive values (Figs. 7a and b). With the discharge of compressive stress stored along the subduction systems, an increase in the cumulative Mrr should be expected over time, as which along the Sumatra and Japan subduction systems. However, in contrast to the cumulated Mrr patterns along the megathrust event areas, the results obtained from Segments A and B infer an extensional stress regime along both the trench and overriding plate suggesting a relatively low stress accumulation. Surprisingly, along Segment C, even though the cumulative Mrr is also affected by negative Mrr events whose influence is very small at only approximately $-5.32 \times 10^{24}$ dyne $\mathrm{cm}^{-1}$ (Fig. $7 \mathrm{c}$ ). The cumulative Mrr temporal variation calculated for the segment is characterized by a 
decrease and then a gradual increase with tiny variations, a pattern similar to the cumulated Mrr pattern observed along the Chile Trench area. This observation infers that Segment $\mathrm{C}$, which is less affected by dilatational stress, may have a relative higher seismic potential than the other segments.

\subsection{Origin of the Tectonic Stress Along the Northern Manila Trench}

As demonstrated by the previous discussion, a dominating extensional stress regime along the northern Manila Trench area is evident. Kao et al. (2000) proposed the existence of a typical subduction zone south of $21.5^{\circ} \mathrm{N}$ clearly shown by both bathymetry and seismicity. In addition, neither tectonic discontinuity nor large tectonic features have been reported along the Manila Trench system. We thus consider that the spatial stress distribution variations could not be induced by the structural heterogeneity or other material variability in the overlying or subducting plates. Some previous work shows that a strongly coupled subduction system could generate extensional cracks in the forearc area (Loveless et al. 2005). In that case, the extensional regime seems to be limited in both size and area. However, the distribution and magnitude of Mrr along our study area show that the extensional regime dominates both the upper and lower plates. Thus, the extensional environment along the northern part of the Manial Trench would most likely originate from the plate decoupling effect.

\subsection{Correlation Between Variations in the Mrr and Plate Coupling}

Several studies have estimated the coupling ratios of the Manila Trench using GPS data (Galgana et al. 2007; Hamburger et al. 2010; Yu et al. 2013; Hsu et al. 2012), and almost zero coupling was proposed, which is consistent with the low seismic potential estimated for Segments A and B, where most of the upper and lower plates are characterized by a negative Mrr distribution and the cumulative Mrr decreases largely as a function of time. Hsu et al. (2012) have discussed GPS, trench parallel gravity anomaly and bathymetry data to infer more detailed plate coupling patterns along the Manila subduction zone; their study enables quantification of the coupling ratio. A partially locked fault patch extending from the West Luzon Trough to the east of the Scarborough Seamount chain has been discovered with a coupling ratio of 0.4 (Hsu et al. 2012). In our result, due to the temporal increase of the cumulative Mrr, a relatively higher seismic potential is estimated for the southern Manila Trench at the position of Segment C, which corresponds to this partially locked area revealed by the inversion of the GPS data.

\section{CONCLUSION}

The seismic potential has been assessed for the Ma- nila Trench area. We undertook an analysis of the seismic behavior of large earthquakes and estimated the crustal deformation state based on the Mrr distribution. Results show that before a large earthquake, both the overriding and the subducting plates are under compressive stress but are characterized by an extensional regime after the mainshock. The temporal variation of the cumulative Mrr generally shows an increasing pattern with a contribution from the outer-rise, plate interface and overriding areas.

In the northern Manila Trench area, the broad zone of extensional seismic activity along the trench reveals a stress state similar to that of the post-seismic environment for large earthquakes; therefore, the release of tectonic stress and the coupling between the plates could be weak. Along the center Manila Trench, only a few extensional earthquakes were located in the outer-rise and near the trench area, and the existence of numerous negative Mrr events in the overriding plate shows that the crust is affected by a dilating regime and thus suggests a low coupling environment. The decreasing cumulated Mrr pattern with time along the northern and central Manila Trench once again suggests a present-day extensional stress regime around the area that is distinct from the patterns observed along the large megathrust event areas. In the southern Manila Trench, except for a few extensional events distributed locally in the Central Valley basin, most earthquakes show compressive mechanisms. We suggest that the plate coupling exists along this portion of the trench and results in stress accumulation not only along the plate interface but also in the neighboring portions of the subducting and overriding plates. In our results, a dominant extensional stress state, generally considered as undertaking a low coupling mechanism, is observed along the northern Manila Trench. Compared to the highly compressive environments along other high seismic potential subduction systems, the probability of a megathrust event in the northern Manila Trench should be not high. Even so, possible destruction produced by earthquakes occurring along the southern part of the Manila Trench and the inland areas of the Philippines should still not be ignored. These latter earthquakes are generally characterized by shallow hypocenters and large magnitudes, such as the $1990 \mathrm{Mw} 7.7$ Luzon earthquake.

Acknowledgements We thank Editor and anonymous reviewers for their helpful comments. Figures were prepared with the Generic Mapping Tool (GMT) software (Wessel and Smith 1998). Support from the Ministry of Science and Technology, Taiwan, under contract No. 104-2811-M-008029 and 104-3113-M-008-001 is gratefully acknowledged.

\section{REFERENCES}

Astiz, L., T. Lay, and H. Kanamori, 1988: Large intermediate-depth earthquakes and the subduction process. Phys. 
Earth Planet. Inter., 53, 80-166, doi: 10.1016/00319201(88)90138-0. [Link]

Barrier, E., P. Huchon, and M. Aurelio, 1991: Philippine fault: A key for Philippine kinematics. Geology, 19, 32-35, doi: 10.1130/0091-7613(1991)019<0032:PFA $\mathrm{KFP}>2.3 . \mathrm{CO}$;2. [Link]

Bautista, B. C., M. L. P. Bautista, K. Oike, F. T. Wu, and R. S. Punongbayan, 2001: A new insight on the geometry of subducting slabs in northern Luzon, Philippines. Tectonophysics, 339, 279-310, doi: 10.1016/S00401951(01)00120-2. [Link]

Christensen, D. H. and L. J. Ruff, 1988: Seismic coupling and outer rise earthquakes. J. Geophys. Res., 93, 1342113444, doi: 10.1029/JB093iB11p13421. [Link]

Cummins, P. R., 2007: The potential for giant tsunamigenic earthquakes in the northern Bay of Bengal. Nature, 449, 75-78, doi: 10.1038/nature06088. [Link]

Dao, M. H., P. Tkalich, E. S. Chan, and K. Megawati, 2009: Tsunami propagation scenarios in the South China Sea. J. Asian Earth Sci., 36, 67-73, doi: 10.1016/j.jseaes.2008.09.009. [Link]

Delouis, B., J. M. Nocquet, and M. Vallée, 2010: Slip distribution of the February 27, $2010 \mathrm{Mw}=8.8$ Maule Earthquake, central Chile, from static and high-rate GPS, InSAR, and broadband teleseismic data. Geophys. Res. Lett., 37, L17305, doi: 10.1029/2010GL043899. [Link]

Dimalanta, C., A. Taira, G. P. Yumul Jr., H. Tokuyama, and K. Mochizuki, 2002: New rates of western Pacific island arc magmatism from seismic and gravity data. Earth Planet. Sci. Lett., 202, 105-115, doi: 10.1016/ S0012-821X(02)00761-6. [Link]

Dimalanta, C. B. and G. P. Yumul Jr., 2004: Crustal thickening in an active margin setting (Philippines): The whys and the hows. Episodes, 27, 260-264.

Dimalanta, C. B. and G. P. Yumul Jr., 2006: Magmatic and amagmatic contributions to crustal growth in the Philippine island arc system: Comparison of the Cretaceous and post-Cretaceous periods. Geosci. J., 10, 321-329, doi: 10.1007/BF02910373. [Link]

Dziewonski, A. M., T. A. Chou, and J. H. Woodhouse, 1981: Determination of earthquake source parameters from waveform data for studies of global and regional seismicity. J. Geophys. Res., 86, 2825-2852, doi: 10.1029/ JB086iB04p02825. [Link]

Ekström, G., M. Nettles, and A. M. Dziewoński, 2012: The global CMT project 2004-2010: Centroid-moment tensors for 13,017 earthquakes. Phys. Earth Planet. Inter., 200-201, 1-9, doi: 10.1016/j.pepi.2012.04.002. [Link]

Galgana, G., M. Hamburger, R. McCaffrey, E. Corpuz, and Q. Chen, 2007: Analysis of crustal deformation in Luzon, Philippines using geodetic observations and earthquake focal mechanisms. Tectonophysics, 432, 63-87, doi: 10.1016/j.tecto.2006.12.001. [Link]
Gusiakov, V. K., 2005: Tsunami generation potential of different tsunamigenic regions in the Pacific. Mar. Geol., 215, 3-9, doi: 10.1016/j.margeo.2004.05.033. [Link]

Hamburger, M. W., G. A. Galgana, T. Bacolcol, R. McCaffrey, and S. Yu, 2010: Analysis of oblique plate convergence along the Manila Trench and the Philippine Trench. American Geophysical Union, Fall Meeting 2010, abstract \#T51D-2084.

Hayes, D. E. and S. D. Lewis, 1984: A geophysical study of the Manila Trench, Luzon, Philippines: 1. Crustal structure, gravity, and regional tectonic evolution. J. Geophys. Res., 89, 9171-9195, doi: 10.1029/ JB089iB11p09171. [Link]

Hsu, Y. J., S. B. Yu, T. R. A. Song, and T. Bacolcol, 2012: Plate coupling along the Manila subduction zone between Taiwan and northern Luzon. J. Asian Earth Sci., 51, 98-108, doi: 10.1016/j.jseaes.2012.01.005. [Link]

Kanamori,H., 1981: The nature of seismicity patterns before large earthquakes. In: Simpson, D. W. and P. G. Richards (Eds.), Earthquake Prediction, Maurice Ewing Series, Vol. 4, American Geophysical Union, Washington, D. C., 1-19, doi: 10.1029/ME004p0001 . [Link]

Kanamori, H., 1986: Rupture process of subduction-zone earthquakes. Annu. Rev. Earth Planet. Sci., 14, 293 322, doi: 10.1146/annurev.ea.14.050186.001453. [Link]

Kao, H. and W. P. Chen, 1991: Earthquakes along the Ryukyu-Kyushu Arc: Strain segmentation, lateral compression, and the thermomechanical state of the plate interface. J. Geophys. Res., 96, 21443-21485, doi: 10.1029/91JB02164. [Link]

Kao, H., S. J. Shen, and K. F. Ma, 1998: Transition from oblique subduction to collision: Earthquakes in the southernmost Ryukyu arc-Taiwan region. J. Geophys. Res., 103, 7211-7229, doi: 10.1029/97JB03510. [Link]

Kao, H., G. C. Huang, and C. S. Liu, 2000: Transition from oblique subduction to collision in the northern Luzon arc-Taiwan region: Constraints from bathymetry and seismic observations. J. Geophys. Res., 105, 30593079, doi: 10.1029/1999JB900357. [Link]

Keilis-Borok, V. I. and V. G. Kossobokov, 1990: Premonitory activation of earthquake flow: Algorithm M8. Phys. Earth Planet. Inter., 61, 73-83, doi: 10.1016/00319201(90)90096-G. [Link]

Kirby, S. H., E. Geist, W.H. K. Lee, D. Scholl, and R. Blakely, 2006: Tsunami source characterization for Western Pacific subduction zones: A preliminary report. USGS Tsunami Sources Workshop, Houston, TX.

Ku, C. Y. and S. K. Hsu, 2009: Crustal structure and deformation at the northern Manila Trench between Taiwan and Luzon islands. Tectonophysics, 466, 229-240, doi: 10.1016/j.tecto.2007.11.012. [Link]

Lay, T., L. Astiz, H. Kanamori, and D. H. Christensen, 1989: Temporal variation of large intraplate earthquakes in 
coupled subduction zones. Phys. Earth Planet.Inter., 54, 258-312, doi: 10.1016/0031-9201(89)90247-1. [Link]

Lay, T., C. J. Ammon, H. Kanamori, K. D. Koper, O. Sufri, and A. R. Hutko, 2010: Teleseismic inversion for rupture process of the 27 February 2010 Chile $\left(M_{w}\right.$ 8.8) earthquake. Geophys. Res. Lett., 37, L13301, doi: 10.1029/2010GL043379. [Link]

Lewis, S. D. and D. E. Hayes, 1989: Plate convergence and deformation, North Luzon Ridge, Philippines. Tectonophysics, 168, 221-237, doi: 10.1016/00401951(89)90377-6. [Link]

Lin, J. Y. and C. L. Lo, 2013: Earthquake-induced crustal gravitational potential energy change in the Philippine area. J. Asian Earth Sci., 66, 215-223, doi: 10.1016/j. jseaes.2013.01.009. [Link]

Liu, P. L. F., X. Wang, and A. J. Salisbury, 2009: Tsunami hazard and early warning system in South China Sea. J. Asian Earth Sci., 36, 2-12, doi: 10.1016/j.jseaes.2008.12.010. [Link]

Liu, Y., A. Santos, S. M. Wang, Y. Shi, H. Liu, and D. A. Yuen, 2007: Tsunami hazards along Chinese coast from potential earthquakes in South China Sea. Phys. Earth Planet. Inter., 163, 233-244, doi: 10.1016/j. pepi.2007.02.012. [Link]

Lomnitz, C., 1994: Fundamentals of Earthquake Prediction, John Wiley \& Sons, New York, 344 pp.

Loveless, J. P., G. D. Hoke, R. W. Allmendinger, G. González, B. L. Isacks, and D. A. Carrizo, 2005: Pervasive cracking of the northern Chilean Coastal Cordillera: New evidence for forearc extension. Geology, 33, 973-976, doi: 10.1130/G22004.1. [Link]

Ludwig, W. J., 1970: The Manila Trench and West Luzon Trough--III. Seismic-refraction measurements. Deep Sea Res. Oceanogr. Abstr., 17, 553-571, doi: 10.1016/0011-7471(70)90067-7. [Link]

Ludwig, W. J., D. E. Hayes, and J. I. Ewing, 1967: The Manila Trench and West Luzon Trough--I. Bathymetry and sediment distribution. Deep Sea Res. Oceanogr. Abstr., 14, 533-544, doi: 10.1016/0011-7471(67)900630. [Link]

Megawati, K., F. Shaw, K. Sieh, Z. Huang, T. R. Wu, Y. Lin, S. K. Tan, and T. C. Pan, 2009: Tsunami hazard from the subduction megathrust of the South China Sea: Part I. Source characterization and the resulting tsunami. J. Asian Earth Sci., 36, 13-20, doi: 10.1016/j. jseaes.2008.11.012. [Link]

Mogi, K., 1984: Temporal variation of crustal deformation during the days preceding a thrust-type great earthquake - The 1944 Tonankai earthquake of magnitude 8.1, Japan. Pure Appl. Geophys., 122, 765-780, doi: 10.1007/BF00876383. [Link]

Moreno, M., M. Rosenau, and O. Oncken, 2010: 2010 Maule earthquake slip correlates with pre-seismic locking of Andean subduction zone. Nature, 467, 198-202, doi: 10.1038/nature09349. [Link]

Pacheco, J. F., L. R. Sykes, and C. H. Scholz, 1993: Nature of seismic coupling along simple plate boundaries of the subduction type. J. Geophys. Res., 98, 1413314159, doi: 10.1029/93JB00349. [Link]

Peterson, E. T. and T. Seno, 1984: Factors affecting seismic moment release rates in subduction zones. J. Geophys. Res.,89,10233-10248,doi: 10.1029/JB089iB12p10233. [Link]

Ramírez-Rojas, A., A. Muñoz-Diosdado, C. G. Pavía-Miller, and F. Angulo-Brown, 2004: Spectral and multifractal study of electroseismic time series associated to the $M_{w}=6.5$ earthquake of 24 October 1993 in Mexico. Nat. Hazards Earth Syst. Sci., 4, 703-709, doi: 10.5194/ nhess-4-703-2004. [Link]

Ruff, L. and H. Kanamori, 1980: Seismicity and the subduction process. Phys. Earth Planet. Inter., 23, 240-252, doi: 10.1016/0031-9201(80)90117-X. [Link]

Scholz, C. H., 1988: The critical slip distance for seismic faulting. Nature, 336, 761-763, doi: 10.1038/336761 a0. [Link]

Sella, G. F., T. H. Dixon, and A. Mao, 2002: REVEL: A model for recent plate velocities from space geodesy. J. Geophys. Res., 107, doi: 10.1029/2000JB000033. [Link]

Seno, T., S. Stein, and A. E. Gripp, 1993: A model for the motion of the Philippine Sea Plate consistent with NUVEL-1 and geological data. J. Geophys. Res., 98, 17941-17948, doi: 10.1029/93JB00782. [Link]

Sieh, K., D. H. Natawidjaja, A. J. Meltzner, C. C. Shen, H. Cheng, K. S. Li, B. W. Suwargadi, J. Galetzka, B. Philibosian, and R. L. Edwards, 2008: Earthquake supercycles inferred from sea-level changes recorded in the corals of west Sumatra. Science, 322, 1674-1678, doi: 10.1126/science.1163589. [Link]

Stein, S. and E. A. Okal, 2005: Seismology: Speed and size of the Sumatra earthquake. Nature, 434, 581-582, doi: 10.1038/434581a. [Link]

Tang, J. C. and A. I. Chemenda, 2000: Numerical modelling of arc-continent collision: Application to Taiwan. Tectonophysics, 325, 23-42, doi: 10.1016/S00401951(00)00129-3. [Link]

Taylor, M. A. J., G. Zheng, J. R. Rice, W. D. Stuart, and R. Dmowska, 1996: Cyclic stressing and seismicity at strongly coupled subduction zones. J. Geophys. Res., 101, 8363-8381, doi: 10.1029/95JB03561. [Link]

Telesca, L., V. Lapenna, and M. Macchiato, 2003: Spatial variability of the time-correlated behaviour in Italian seismicity. Earth Planet. Sci. Lett., 212, 279-290, doi: 10.1016/S0012-821X(03)00286-3. [Link]

Thatcher, W., 1990: Order and diversity in the modes of Circum-Pacific Earthquake recurrence. J. Geophys. Res., 95, 2609-2623, doi: 10.1029/JB095iB03p02609. [Link] 
Tsai, V. C., M. Nettles, G. Ekström, and A. M. Dziewonski, 2005: Multiple CMT source analysis of the 2004 Sumatra earthquake. Geophys. Res. Lett., 32, L17304, doi: 10.1029/2005GL023813. [Link]

Turcotte, D. L., 1991: Earthquake prediction. Annu. Rev. Earth Planet. Sci., 19, 263-281, doi: 10.1146/annurev. ea.19.050191.001403. [Link]

Uchida, N. and T. Matsuzawa, 2011: Coupling coefficient, hierarchical structure, and earthquake cycle for the source area of the 2011 off the Pacific coast of Tohoku earthquake inferred from small repeating earthquake data. Earth Planets Space, 63, 675-679, doi: 10.5047/ eps.2011.07.006. [Link]

Wessel, P. and W. H. F. Smith, 1998: New, improved version of generic mapping tools released. Eos, Trans., $A G U, 79,579$, doi: 10.1029/98EO00426. [Link]

Wu, T. R. and H. C. Huang, 2009: Modeling tsunami hazards from Manila trench to Taiwan. J. Asian Earth Sci., 36, 21-28, doi: 10.1016/j.jseaes.2008.12.006. [Link]

Wu, W. N., H. Kao, S. K. Hsu, C. L. Lo, and H. W. Chen, 2010: Spatial variation of the crustal stress field along the Ryukyu-Taiwan-Luzon convergent boundary. J. Geophys. Res., 115, B11401, doi: 10.1029/2009JB007080.
[Link]

Wyss, M. and R. E. Habermann, 1988: Precursory seismic quiescence. Pure Appl. Geophys., 126, 319-332, doi: 10.1007/BF00879001. [Link]

Yang, T. F., T. Lee, C. H. Chen, S. N. Cheng, U. Knittel, R. S. Punongbayan, and A. R. Rasdas, 1996: A double island arc between Taiwan and Luzon: Consequence of ridge subduction. Tectonophysics, 258, 85-101, doi: 10.1016/0040-1951(95)00180-8. [Link]

Yu, S. B., L. C. Kuo, R. S. Punongbayan, and E. G. Ramos, 1999: GPS observation of crustal deformation in the Taiwan-Luzon region. Geophys. Res. Lett., 26, 923926, doi: 10.1029/1999GL900148. [Link]

Yu, S. B., Y. J. Hsu, T. Bacolcol, C. C. Yang, Y. C. Tsai, and R. Solidum, 2013: Present-day crustal deformation along the Philippine Fault in Luzon, Philippines. J. Asian Earth Sci., 65, 64-74, doi: 10.1016/j.jseaes.2010.12.007. [Link]

Yumul, G. P., Jr., C. B. Dimalanta, V. B. Maglambayan, and E. J. Marquez, 2008: Tectonic setting of a composite terrane: A review of the Philippine island arc system. Geosci.J., 12, 7-17, doi: 10.1007/s12303-0080002-0. [Link] 